\title{
Atomic Layer Deposition of Tin Monosulfide Using Vapor from Liquid Bis(N,N\#- diisopropylformamidinato)tin(II) and H2S
}

\section{Citation}

Kim, Sang Bok, Xizhu Zhao, Luke M Davis, Ashwin Jayaraman, Chuanxi Yang, and Roy G Gordon. "Atomic Layer Deposition of Tin Monosulfide Using Vapor from Liquid Bis(N,N"diisopropylformamidinato)tin(II) and H2S." ACS Applied Materials \& Interfaces 11, no. 49 (2019): 45892-5902.

\section{Permanent link}

http://nrs.harvard.edu/urn-3:HUL.InstRepos:42640962

\section{Terms of Use}

This article was downloaded from Harvard University's DASH repository, and is made available under the terms and conditions applicable to Open Access Policy Articles, as set forth at http:// nrs.harvard.edu/urn-3:HUL.InstRepos:dash.current.terms-of-use\#OAP

\section{Share Your Story}

The Harvard community has made this article openly available.

Please share how this access benefits you. Submit a story.

\section{Accessibility}




\title{
Atomic Layer Deposition of Tin Monosulfide Using Vapor from Liquid Bis( $N, N^{\prime}$-diisopropylformamidinato)tin(II) and $\mathrm{H}_{2} \mathrm{~S}$
}

\author{
Sang Bok Kim,\# Xizhu Zhao, ${ }^{\dagger}$ Luke M. Davis, ${ }^{\S}$ Ashwin Jayaraman, ${ }^{\ddagger}$ Chuanxi Yang, ${ }^{\partial}$ and Roy G. \\ Gordon.*
}

Department of Chemistry and Chemical Biology, Harvard University, 12 Oxford Street, Cambridge, MA 02138, USA.

KEYWORDS: ALD, tin monosulfide, QCM, growth per cycle, amidinate, surface reaction, solar cell

\begin{abstract}
The oxide and sulfide of divalent tin show considerable promise for sustainable thin-film optoelectronics, as transparent conducting and light absorbing p-type layers, respectively. Chemical vapor deposition (CVD) and atomic layer deposition (ALD) provide attractive routes to these layers. The literature on volatile tin(II) compounds used as CVD or ALD precursors shows that new compounds can provide different growth rates, film morphologies, preferred crystallographic orientations, and other material properties. We report here the synthesis and characterization of a new liquid tin(II) precursor, bis $\left(N, N^{\prime}\right.$-diisopropylformamidinato)tin(II) (1), which is effective in ALD of $\mathrm{SnS}$ in combination with $\mathrm{H}_{2} \mathrm{~S}$ between 65 and $180^{\circ} \mathrm{C}$. Like other highly reactive tin(II) precursors, the growth per cycle linearly decreases from $0.82 \AA /$ cycle at $65^{\circ} \mathrm{C}$ to $0.4 \AA$ A $/$ cycle at $180{ }^{\circ} \mathrm{C}$. This is obviously different from the case of previously reported SnS ALD using bis(2,4pentanedionato)tin(II), Sn(acac) 2 , and $\mathrm{H}_{2} \mathrm{~S}$; films grow at 0.22-0.24 $\AA$ /cycle almost independent of the substrate temperature $\left(125-225^{\circ} \mathrm{C}\right.$, J. Phys. Chem. C 2010, 114, 17597). Quartz crystal microbalance (QCM) experiments for SnS ALD using 1 at 80,120 , and $160^{\circ} \mathrm{C}$ were carried out to study the linear decrease of the growth per cycle with increasing substrate temperature. Based on these QCM studies, although the mechanism of chemisorption-loss of one ligand or two-can be manipulated by changing the exposure of $\mathbf{1}$, the purging time, or the temperature, only the temperature changes the growth per cycle. We therefore attribute the decreasing growth per cycle with increasing temperature to a decreasing surface thiol density. Photovoltaic devices prepared from 1-derived SnS have similar performance to the best devices prepared from other precursors, and the device yield and replicability of J-V properties are substantially increased by using 1.
\end{abstract}

\section{Introduction}

Volatile tin(II) compounds suitable for use in atomic layer deposition (ALD) ${ }^{1-3}$ have attracted significant attention recently. These molecules have applications in the ALD of solar cell absorbers such as $\mathrm{SnS},^{4-6}$ and transparent conducting oxides (TCOs) of both n-type, as $\mathrm{SnO}_{2},{ }^{7}$ and p-type, as SnO. ${ }^{8}$ The applications of ALD SnS films in thin film transistors (TFT) and gas sensors were recently reported. ${ }^{9-}$ ${ }^{10}$ The ALD of p-type $\mathrm{SnS}^{11}$ and $\mathrm{SnO}^{8}$ films is of special interest to us. Tin monoxide may meet the growing demand for a thin-film p-type transparent conductor. ${ }^{8,12-13}$

Tin monosulfide may enable widespread deployment of thin-film photovoltaics. Commercially available thin-film photovoltaic devices have excellent champion power conversion efficiency (PCE), for both $\mathrm{CuIn}_{x} \mathrm{Ga}_{(1-x)} \mathrm{Se}_{2}$ (CIGS, PCE: $21.7 \%)^{14}$ and CdTe (PCE: 20.4\%). ${ }^{15}$ Unfortunately, these devices rely on expensive indium and toxic cadmium. As a solution to these problems in CIGS and CdTe,
$\mathrm{Cu}_{2} \mathrm{ZnSn}(\mathrm{S}, \mathrm{Se})_{4}$ (CZTS, PCE: $\left.12.6 \%\right)^{16}$ has been studied as a promising solar cell light absorber material. However, antisite defects have presented a formidable obstacle to further optimization in this system.17-19 The demand for an earth abundant (low-cost), simple, non-toxic photovoltaic system remains unmet, and SnS has attracted significant attention in this context in recent years. ${ }^{3-6,20-22} \mathrm{SnS}$ has a direct optical band gap ca. $1.3 \mathrm{eV}$, better light absorption than silicon, and has been used as light absorber in photovoltaic devices of up to ca. 5\% efficiency. ${ }^{3-6}$

Although various methods for the deposition of SnS films exist-including solution methods such as chemical bath deposition and electrodeposition-vacuum methods such as chemical vapor deposition (CVD), ${ }^{23} \mathrm{ALD}^{4}$ and thermal evaporation $^{20}$ afford the best photovoltaic devices. One advantage of vacuum methods in growing $\mathrm{SnS}$ is the ease of avoiding potential oxidation of tin(II) resulting in formation of n-type tin(IV) sulfide, ${ }^{11}$ which is not suitable as a solar cell absorber because of its wide band gap (ca. 2.2-2.4 
eV). ${ }^{24}$ Of the vacuum methods, ALD is a good way of obtaining conformal and uniform films on large substrate areas due to its self-limiting surface chemical reactions. ${ }^{25}$ An additional promise of ALD resides in reports that the orientation in the polycrystalline film can be affected by the ALD precursor, kind of substrate, deposition temperature, purging time (ALD deposition time is largely governed by purging because it is usually the longest ALD step), and film thickness. ${ }^{26-27}$ Because of the anisotropy in charge transport properties of orthorhombic SnS, the preferred orientation and the extent of randomness of orientation in the polycrystalline SnS solar cell absorber are important regarding efficiently collecting photogenerated electrons and holes; both the metastable cubic phase and the orthorhombic orientation having the SnS layers perpendicular to the substrate are desired., 28-29

In order to produce SnS ALD films that have optimal properties for a solar cell absorber, it is worthwhile to continue to explore ALD of SnS films by use of many different precursors in many different film growth conditions. The five tin(II) precursors shown in Scheme 1 have been studied for the ALD of SnS: $N, N^{\prime}$-di-tert-butyl-2,3diamidobutanetin(II), $\quad \mathbf{2 ;}^{1,} \quad 5 \quad \operatorname{bis}\left(N, N^{\prime}\right.$ diisopropylacetamidinato)tin(II), $\quad \mathbf{3}^{1^{1,}} \quad 3 \quad \operatorname{bis}(2,4-$ pentanedionato)tin(II), $\quad \operatorname{Sn}($ acac $) 2, \quad 4 ;^{2}$ and bis(1dimethylamino-2-methyl-2-propoxy)tin(II), Sn(dmamp)2, 5. ${ }^{9}$ Compounds 1, $\mathbf{4}$ and $\mathbf{5}$ are liquids at room temperature, whereas compounds $\mathbf{2}$ and $\mathbf{3}$ are solids.

\section{Scheme 1. Tin(II) precursors}

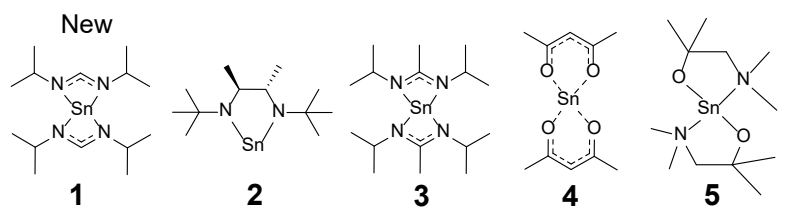

Each tin(II) precursor showed different behavior in the ALD of SnS films using $\mathrm{H}_{2} \mathrm{~S}$ as the sulfur source. In the case of the very volatile $2,{ }^{1,5}$ ALD was performed from the low temperature of $50{ }^{\circ} \mathrm{C}$; the measured growth per cycle was $1.25 \AA$ Acycle at $50-125^{\circ} \mathrm{C}$. At $150{ }^{\circ} \mathrm{C}$, the growth decreased significantly to $0.58 \AA$ /cycle, and $0.42 \AA$ /cycle at $200{ }^{\circ} \mathrm{C} .1$ Only the cubic phase of $\mathrm{SnS}$ was found in films grown at 70 or $120^{\circ} \mathrm{C}^{5}$ In contrast, in SnS ALD using 3, only the orthorhombic phase is found in the ALD window of $100-200{ }^{\circ} \mathrm{C}$, with the growth per cycle initially reported to be 0.86 $\AA$ /cycle. ${ }^{3}$ However, a later report provides a growth per cycle of $0.33 \AA$ /cycle at $200{ }^{\circ} \mathrm{C}^{30} \mathrm{~A}$ careful review of all available data on this precursor and our extensive experience with its use in ALD supports the latter value. The discrepancy appears to result from incomplete purging of $\mathrm{H}_{2} \mathrm{~S}$ from the reactor in the former case, leading to some CVD growth. The growth per cycle of SnS ALD using $\mathbf{4}^{2}$ is much lower, at $0.24 \AA$ / cycle from $125-175^{\circ} \mathrm{C}$; at higher temperatures the growth per cycle decreases slightly, to 0.19 $\AA /$ cycle at $220^{\circ} \mathrm{C}$. In the case of $5,^{8-9}$ the ALD of SnS was performed at $90-240{ }^{\circ} \mathrm{C}$. The growth per cycle was studied only from $90-150{ }^{\circ} \mathrm{C}$, where it is $0.36-0.45 \AA$ /cycle, but quartz crystal microbalance (QCM) studies showed a de- creased mass gain per cycle between 150 and $240{ }^{\circ} \mathrm{C}$. The cubic phase dominates films grown from 90 to $150{ }^{\circ} \mathrm{C}$, and the orthorhombic phase is dominant from 210 to $240{ }^{\circ} \mathrm{C}$, with a preferred (040) orientation.

As shown by this literature summary, a variety of process and materials properties appear to be dictated by choice of precursor. These properties include the ALD window and the temperature dependence of the film growth per cycle, as well as the phase of SnS and the preferred orientation thereof. Therefore, the development of new precursors may be useful in optimizing $\mathrm{SnS}$ or $\mathrm{SnO}$ depositions for a specific purpose. To this end, we sought to prepare a new precursor, drawing on our recent work showing enhanced volatility and reactivity for calcium(II) and indium(III) compounds of the diisopropylformamidinate ligand compared with the diisopropylacetamidinate congeners. ${ }^{31-32}$

Herein, we report a new liquid tin(II) precursor, bis $\left(N, N^{\prime}\right.$-diisopropylformamidinato)tin(II) (1, scheme 1). We have characterized the new compound and its ALD behavior, and prepared photovoltaic devices from the ALD SnS films. Several features of $\mathbf{1}$ and its ALD films merit particular notice.

First, $\mathbf{1}$ is found to be thermally stable at least up to $250{ }^{\circ} \mathrm{C}$ from thermogravimetric analysis (TGA) experiments (Figure 1a). The evaporation rate of $\mathbf{1}$ at $100{ }^{\circ} \mathrm{C}$, obtained by isothermal TGA, is found to be $4.4 \times$ greater than its close relative $\mathbf{3}$ (Figure $1 \mathrm{~b}$ ).

Second, owing to the high volatility and reactivity of $\mathbf{1}$, ALD of SnS using 1 and $\mathrm{H}_{2} \mathrm{~S}$ could be operated even at the low temperature of $65{ }^{\circ} \mathrm{C}$ without precursor condensation $^{25}$ or incomplete reaction. ${ }^{25}$ Pure SnS films without carbon contamination were obtained in the temperature range of $65-180^{\circ} \mathrm{C}$.

Third, we were intrigued to observe that the growth per cycle for 1 decreases linearly from 0.86 to $0.3 \AA$ /cycle as temperature increases from 65 to $200{ }^{\circ} \mathrm{C}$. Although selflimiting behavior in the surface reactions was observed at several temperatures in this range, the growth per cycle profile is different from the traditional temperatureindependence of ALD growth. ${ }^{25}$ A decrease of the ALD growth per cycle with increasing deposition temperature has been reported in SnS using 2, 3, 5, and to a lesser extent 4, as well as $\mathrm{CdS},{ }^{33} \mathrm{ZnS},{ }^{34} \mathrm{In}_{2} \mathrm{~S}_{3},{ }^{35} \mathrm{PbS},{ }^{36} \mathrm{Ga}_{2} \mathrm{~S}_{3},{ }^{37}$ and GeS. ${ }^{1}$ Previous explanations of decreasing growth per cycle have included entropy-driven decreases in chemisorbed metal precursor surface coverage (for CdS) ${ }^{33}$ and changes in surface chemistry, including desorption of chemisorbed metal precursor (e.g., chemisorbed 4 by $\mathrm{H}_{2} \mathrm{~S}$ for $\left.\mathrm{SnS}\right)^{2}$ Many other cases are attributed to decreasing functional group coverage with increasing temperature. ${ }^{38}$

We undertook studies with a quartz crystal microbalance (QCM) to understand the decrease of the growth per cycle with increasing temperature in the present SnS ALD. On the basis of the QCM data, we attribute this decrease to entropy-driven decreases in the equilibrium surface coverage of thiol groups. The QCM studies revealed changes in the chemisorption of $\mathbf{1}$ with changes in the ALD tempera- 
ture, exposure time of $\mathbf{1}$, and nitrogen purging time; these surface chemistry changes alone, however, did not give rise to the changing growth per cycle.

Fourth, after demonstrating conformal ALD of SnS, the utility of these films as light-absorbing layers in photovoltaic cells was examined. Cells were fabricated and compared with nearly identical devices prepared using $\mathbf{3}$ as the tin source; the 1-derived devices uniformly exhibited comparable performance to the best 3 -derived cell. Thus, the device yield and performance were enhanced by using the new precursor, although further optimization of the device design and fabrication to enhance the PCE remains an outstanding challenge.

\section{Results and Discussion}

\subsection{ALD Growth.}

$\operatorname{Bis}(N, N$ '-diisopropylformamidinato)tin(II), 1, was prepared from the reaction of $\mathrm{SnCl}_{2}$ with lithium formamidinate. The air- and moisture-sensitive colorless liquid was isolated in $68 \%$ yield by distillation, and its purity ascertained by ${ }^{1} \mathrm{H}$ and ${ }^{13} \mathrm{C}$ NMR as well as elemental microanalysis. As observed for other tin compounds such as bis(cyclopentadienyl)tin(II) $\left(J 117 / 11{ }^{S}{ }^{-}{ }^{1} \mathrm{H}=15.3 \mathrm{~Hz}\right),{ }^{39-40}$ and some cyclopentadienyltin(IV) derivatives $\left(\mathrm{J}_{117 / 119} \mathrm{Sn}^{1}{ }^{1} \mathrm{H}=29\right.$ $46.5 \mathrm{~Hz}),{ }^{41}$ the nuclear spins of the two $I=1 / 2$ isotopes of tin, ${ }^{117} \mathrm{Sn}$ and ${ }^{119} \mathrm{Sn}(7.67 \%$ and $8.68 \%$ natural abundance $),{ }^{40}$ couple to the methine proton of the formamidinate backbone with $J_{117 / 119}{ }_{S n}{ }^{1} H=38 \mathrm{~Hz}$. The synthesis of $\mathbf{1}$ can be performed on a 20 -gram scale.

a)

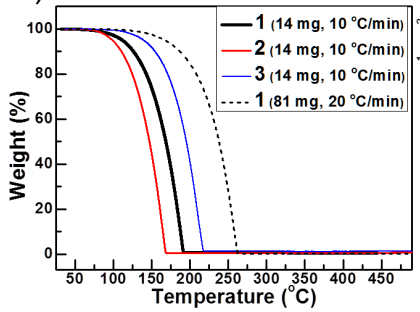

b)

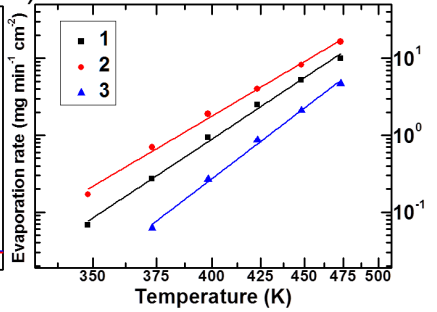

Figure 1. a) TGA curves (ramp) of $\mathbf{1}$ (black line, $14 \mathrm{mg}$, $10{ }^{\circ} \mathrm{C} / \mathrm{min}$ ), 2 (red line, $14 \mathrm{mg}, 10^{\circ} \mathrm{C} / \mathrm{min}$ ), 3 (blue line, $14 \mathrm{mg}$, $10{ }^{\circ} \mathrm{C} / \mathrm{min}$ ), and 1 (dashed line, $81 \mathrm{mg}, 20{ }^{\circ} \mathrm{C} / \mathrm{min}$ ); b) plot of evaporation rate $\left(\mathrm{mg} \mathrm{min}^{-1} \mathrm{~cm}^{-2}\right.$, log scale) vs. temperature (Kelvin, reciprocal scale), based on weight loss at each temperature for 15 min: $\mathbf{1}$ (black squares and line), $\mathbf{2}$ (red circles and line), and $\mathbf{3}$ (blue triangles and line).

To compare the volatility and thermal stability during evaporation of $\mathbf{1}$ with those of $\mathbf{2}$ and 3, which have been studied for ALD of light-absorbing SnS in our group, TGA experiments were performed for all three compounds. Figure 1 a shows that $\mathbf{1}, \mathbf{2}$, and $\mathbf{3}$ evaporate completely in a single step without leaving residues from thermal decomposition. By utilizing a faster heating rate $\left(20^{\circ} \mathrm{C} / \mathrm{min}\right)$ and larger amount of compound ( $81 \mathrm{mg}$ ), the complete evaporation of 1 can be shifted to higher temperature, providing more information on the thermal stability of the molecule. The result demonstrates thermal stability on the TGA timescale up to at least $250{ }^{\circ} \mathrm{C}$ for $\mathbf{1}$. In the log-reciprocal plot of figure $1 \mathrm{~b}$, the evaporation rates of $\mathbf{1}, \mathbf{2}$, and $\mathbf{3}$ in- crease linearly with temperature, from 75 to $200{ }^{\circ} \mathrm{C}$ for $\mathbf{1}$ and 2 , and from 100 to $200{ }^{\circ} \mathrm{C}$ for 3 . This linearity confirms a single mass-loss mechanism (evaporation). The evaporation rate of $\mathbf{1}$ is clearly higher than that of $\mathbf{3}$ and lower than that of $\mathbf{2}$. Notably, the evaporation rate of $\mathbf{1}$ (liquid) is 4.4 times higher than that of $\mathbf{3}$ which is a congener of $\mathbf{1}$. From Figure 1b, we can estimate the heating temperatures necessary to afford the same evaporation rate. For instance, to obtain an evaporation rate of $0.25 \mathrm{mg} \mathrm{min}^{-1} \mathrm{~cm}^{-2}, 1$ requires heating to ca. $100{ }^{\circ} \mathrm{C}$ whereas 3 must be heated ca. $25{ }^{\circ} \mathrm{C}$ higher (more volatile $\mathbf{2}$ has the same evaporation rate ca. $20^{\circ} \mathrm{C}$ lower than $\mathbf{1}$ ).
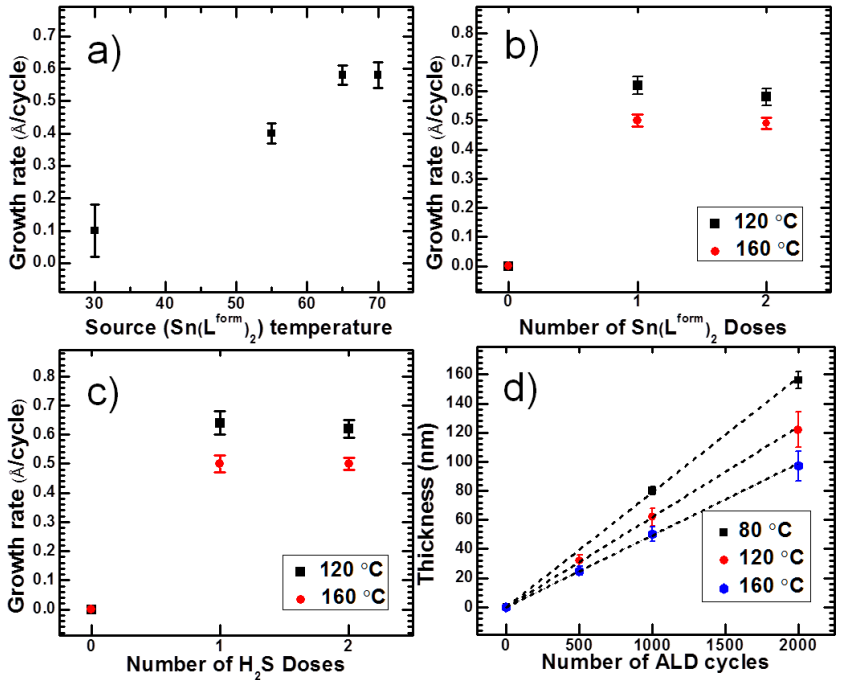

Figure 2. Growth per cycle vs. a) source temperatures for 1, b) number of doses of $\mathbf{1}$, and c) number of $\mathrm{H}_{2} \mathrm{~S}$ doses; d) shows thickness vs. number of ALD cycles.

An ALD growth process was demonstrated for $\mathbf{1}$ by showing saturation behavior in each precursor and linear variation in film thickness with cycle number. These studies were performed with a recipe of one dose $(1 \mathrm{~s})$ of 1 (held in the reactor for $3 \mathrm{~s}$ ) $\rightarrow \mathrm{N}_{2}$ purge (opened to pump with flow of $\mathrm{N}_{2}$ for $10 \mathrm{~s}$ ) $\rightarrow$ evacuation (opened to pump without flow of $\mathrm{N}_{2}$ for $10 \mathrm{~s}$ ) $\rightarrow$ one dose (1 s) of $\mathrm{H}_{2} \mathrm{~S}$ (held in the reactor for $1 \mathrm{~s}) \rightarrow \mathrm{N}_{2}$ purge (10 s) $\rightarrow$ evacuation (10 s). First, holding the substrate temperature constant at $120{ }^{\circ} \mathrm{C}$, the source temperature was varied, as shown in figure $2 \mathrm{a}$; the growth per cycle increases from 30 to $65^{\circ} \mathrm{C}$ and remains constant from 65 to $70{ }^{\circ} \mathrm{C}$. Holding the source temperature at $65{ }^{\circ} \mathrm{C}$, the dependence of the growth per cycle on the number of doses of each of 1 and $\mathrm{H}_{2} \mathrm{~S}$ was studied at substrate temperatures of $120^{\circ} \mathrm{C}$ and $160{ }^{\circ} \mathrm{C}$. As shown in figure $2 \mathrm{~b}, \mathrm{c}$, saturation is achieved with one dose of each precursor. Figure $2 \mathrm{~d}$ shows the linear relationship between the film thickness and the number of cycles, which is usually characteristic of ALD growth, at three different growth temperatures. 


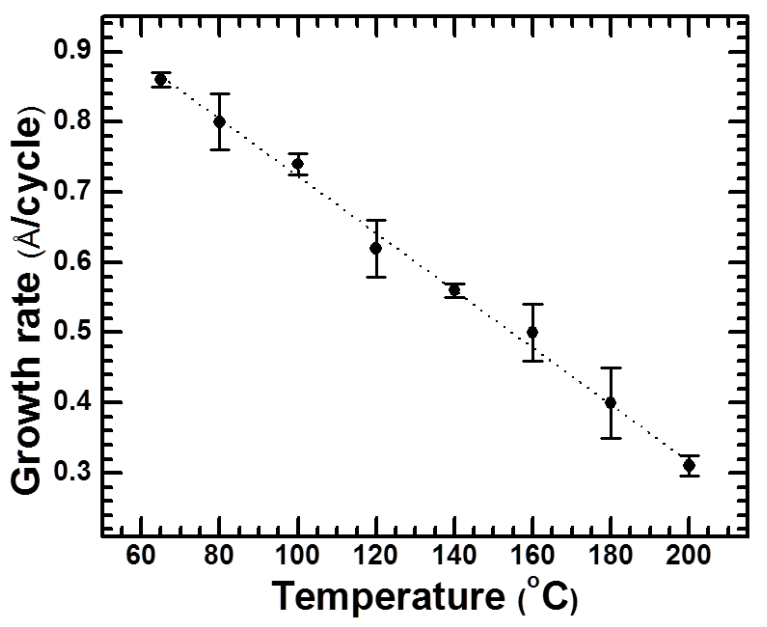

Figure 3. Variation in ALD growth per cycle with temperature using 1 and $\mathrm{H}_{2} \mathrm{~S}$. The error bars represent the range of thickness values measured from 3 or more locations from 1 sample or from 2 samples deposited using the same condition but on different days.

ALD of SnS using 1 and $\mathrm{H}_{2} \mathrm{~S}$ was performed in the temperature range of $65-200{ }^{\circ} \mathrm{C}$. Surprisingly, given the demonstrated ALD behavior, the growth per cycle was found to decrease linearly with increasing temperature from 65 to $200{ }^{\circ} \mathrm{C}$ (Figure 3). From X-ray photoelectron spectroscopy (XPS) studies, the films contain pure, stoichiometric SnS. The Sn:S ratio does not vary as a function of temperature, and remains within $5 \%$ of $1: 1$ at all temperatures (Figure S6). The films were carbon-free up to $180^{\circ} \mathrm{C}$ but ca. $9 \%$ carbon was found in the film grown at $200{ }^{\circ} \mathrm{C}$ (Figure S1). The surface reactions involving $\mathbf{1}$ and $\mathrm{H}_{2} \mathrm{~S}$ therefore proceed to completion without leaving organic residues in the temperature range of $65-180{ }^{\circ} \mathrm{C}$. Thermal decomposition of the precursor or its by-products on the growth surface is common at the upper end of ALD temperature windows. Oxygen and nitrogen are also below the XPS detection limit (ca. 1 at. \%) in the temperature range 65 to $180^{\circ} \mathrm{C}$.

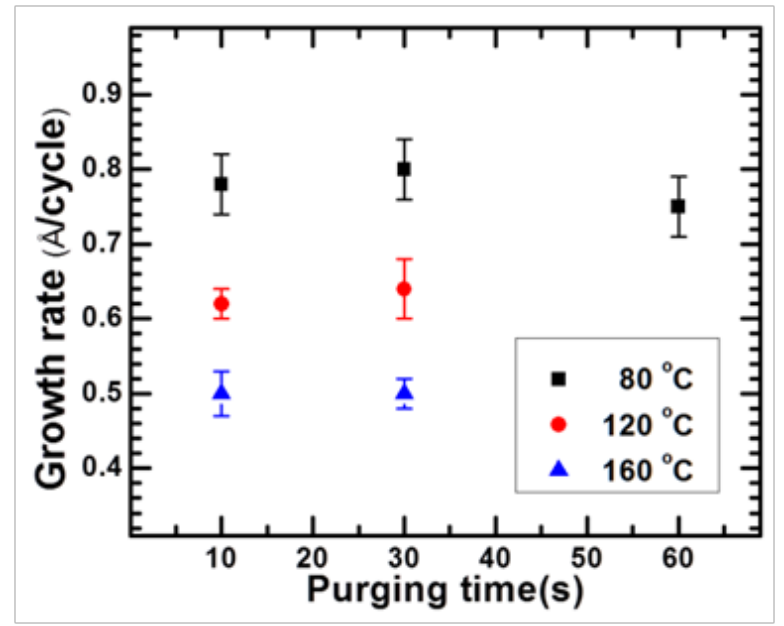

Figure 4. Purging time vs. growth per cycle $(\AA /$ cycle $)$ of ALD (1,000 cycles) using 1 and $\mathrm{H}_{2} \mathrm{~S}$ at $80^{\circ} \mathrm{C}$ (black squares), $120^{\circ} \mathrm{C}$ (red circles), and $160^{\circ} \mathrm{C}$ (blue triangles). The error bars represent the same thickness measurement variation as described in Figure 3.

A common cause of changing growth per cycle in apparent ALD is some contribution from a CVD process. This origin can be considered especially likely when the ALD reaction onset is a low temperature like $65^{\circ} \mathrm{C}$ or when the growth per cycle is unusually high at low temperatures. Such a CVD process could result from incomplete removal of either gas-phase or physisorbed species during one or both portions of the ALD cycle. Indeed, just such a behavior gives rise to the high growth per cycle initially reported for $3,{ }^{3}$ despite attempts to ensure complete removal and verify saturation. Any CVD component to the growth should be diminished by longer purging times. Figure 4 shows that for 1 , the purging time has close to no effect on the growth per cycle at any temperature studied even at very long purging times. Therefore, it can be concluded that the decrease of the growth per cycle with increasing temperature is not the result of gas phase reactions, or from condensed or physisorbed 1 or $\mathrm{H}_{2} \mathrm{~S}$.

\subsection{Reaction Mechanism.}

Having ruled out a CVD component, we became interested in the origin of the decrease of the ALD growth per cycle with increasing temperature for $\mathbf{1}$ and $\mathrm{H}_{2} \mathrm{~S}$. If a typical ALD mechanism operates in the growth of $\mathrm{SnS}$ from 1 and $\mathrm{H}_{2} \mathrm{~S}$, the growth per cycle will be limited either by the areal density of thiol groups on the surface or by the steric demand of the formamidinate ligand on the surface. ${ }^{26,42}$ In this context, it is striking that all of the other ALD SnS precursors, excepting perhaps the least reactive one, 4, display a decreasing growth per cycle at higher temperature, with the highest value at $200{ }^{\circ} \mathrm{C}$ being just $0.42 \AA$ /cycle for 2 . The similarity of the temperature dependence suggests a common mechanism for the trend. It has been proposed that entropic effects at increasing temperature can give rise to decreased surface coverage by metal precursors. ${ }^{33}$ On the other hand, changes in the surface chemistry, such as the surface thiol density, could also be the origin. ${ }^{38}$ Some changes in surface chemistry can be teased apart using QCM. 2,38

Two idealized limiting cases provide an example of how reaction mechanisms can be distinguished via QCM. In the canonical ALD reaction $\mathrm{A} \rightarrow \mathrm{B} \rightarrow \mathrm{C}$ in Figure 5, addition of 1 to a thiol-terminated surface eliminates one formamidine and chemisorbs a tin monoformamidinate fragment to the surface $(\mathrm{A} \rightarrow \mathrm{B})$. A second formamidine ligand is freed upon exposure to $\mathrm{H}_{2} \mathrm{~S}$, and a thiolterminated surface is regenerated but with one SnS added $(B \rightarrow C)$. After the first step $(A \rightarrow B)$, the mass change on the surface corresponds to the molecular weight of $\mathbf{1} \mathrm{mi}-$ nus the m.w. of a formamidine ligand, i.e., $\Delta \mathrm{m}_{1}=\mathrm{SnL}_{2}-\mathrm{HL}$. After the second step $(\mathrm{B} \rightarrow \mathrm{C}$ ), the mass change on the surface is similarly $\Delta \mathrm{m}_{2}=\mathrm{H}_{2} \mathrm{~S}-\mathrm{HL}$. The total mass change of one ALD cycle will be $\Delta \mathrm{m}_{1}+\Delta \mathrm{m}_{2}=\mathrm{SnS}$, and evaluating the ratio $\Delta \mathrm{m}_{2} / \Delta \mathrm{m}_{1}$ affords -0.38 . In the alternative mechanism in Figure 5, $\mathrm{A} \rightarrow \mathrm{E} \rightarrow \mathrm{C}$, addition of $\mathbf{1}$ to a thiol-terminated surface eliminates two formamidine ligands, generating a tin-bridged surface $(\mathrm{A} \rightarrow \mathrm{E})$. Exposure to $\mathrm{H}_{2} \mathrm{~S}$ regenerates a 
thiol-terminated surface by addition across one $\mathrm{Sn}-\mathrm{S}$ bond $(\mathrm{E} \rightarrow \mathrm{C})$. Here, $\Delta \mathrm{m}_{1}=\mathrm{SnL}_{2}-2 \mathrm{HL}$ and $\Delta \mathrm{m}_{2}=\mathrm{H}_{2} \mathrm{~S}$. Thus, although the total mass change of one ALD cycle will still be $\Delta \mathrm{m}_{1}+\Delta \mathrm{m}_{2}=\mathrm{SnS}$, the ratio $\Delta \mathrm{m}_{2} / \Delta \mathrm{m}_{1}$ is now +0.29 .

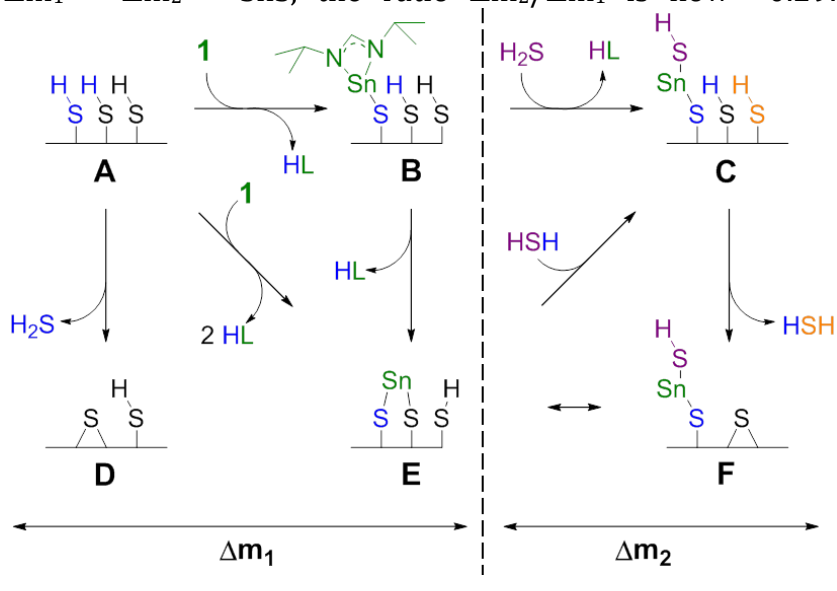

Figure 5. Depiction of one cycle of a canonical ALD mechanism for 1 and $\mathrm{H}_{2} \mathrm{~S}, \mathrm{~A} \rightarrow \mathrm{B} \rightarrow \mathrm{C}$, in which one ligand is freed from the surface in each step of the process; along with an alternative ALD mechanism, $\mathrm{A} \rightarrow \mathrm{E} \rightarrow \mathrm{C}$, in which two ligands are freed in the first step and the surface thiols are regenerated in the second step. The reactions $\mathrm{A} \rightarrow \mathrm{D}$ and $\mathrm{C} \rightarrow \mathrm{F}$ indicate recombination of surface thiols to release $\mathrm{H}_{2} \mathrm{~S}$, and the reaction $\mathrm{B} \rightarrow \mathrm{E}$ indicates reaction of a surface thiol with a surface ligand to eliminate HL, the free ligand diisopropylformamidine.

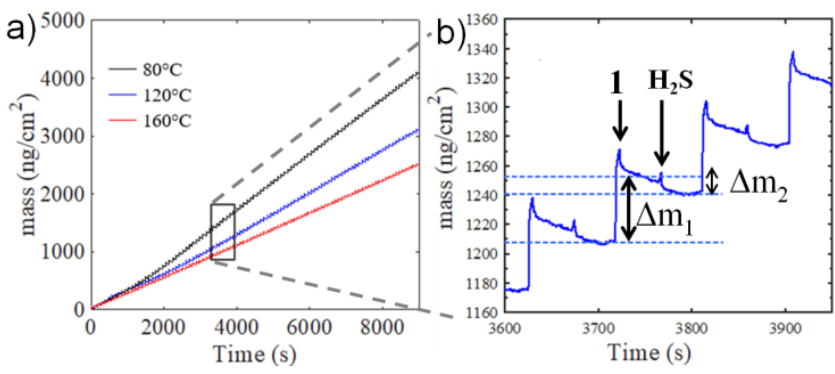

Figure 6. QCM measurements of mass gain during 100 cycles of SnS ALD on sputtered molybdenum film (500 nm) on a gold-coated quartz crystal at 80,120 , and $160^{\circ} \mathrm{C}$. a) Mass gain vs. time at $80{ }^{\circ} \mathrm{C}$ (red solid), $120^{\circ} \mathrm{C}$ (blue solid), and $160{ }^{\circ} \mathrm{C}$ (black solid); b) Close-up of mass gain vs time for three cycles of SnS ALD at $120^{\circ} \mathrm{C}$ as shown in figure 6 a.

In order to further explore the nonstandard ALD behavior of this SnS process, several QCM experiments were performed. QCM measurements of the mass gain during 100 cycles of SnS ALD on a sputtered molybdenum film (500 $\mathrm{nm}$ ) on a gold-coated quartz crystal at three temperatures $\left(80,120\right.$, and $\left.160^{\circ} \mathrm{C}\right)$ are shown in Figure 6. These results were obtained using a recipe of one dose (1 s) of $\mathbf{1}$ (held in the reactor for $3 \mathrm{~s}$ ); exposure time: $4 \mathrm{~s} \rightarrow \mathrm{N}_{2}$ purge (30 s) $\rightarrow$ evacuation (10 s) $\rightarrow$ one dose (1 s) of $\mathrm{H}_{2} \mathrm{~S}$ (held in the reactor for $3 \mathrm{~s}$ ); exposure time: $4 \mathrm{~s} \rightarrow \mathrm{N}_{2}$ purge (30 s) $\rightarrow$ evacuation (10 s). The time of one complete SnS ALD cycle is therefore $88 \mathrm{~s}$. Aside from the first 18 cycles (ca. $1600 \mathrm{~s}$ ) of ALD at $80^{\circ} \mathrm{C}$, the mass gain is very linear versus time, as shown in Figure 6a. The lower slope up to ca. $1600 \mathrm{~s}$ in that case reflects a lower growth per cycle during the nucleation period, prior to full surface coverage of SnS. The lack of a nucleation period in the other two studies results from using the same crystal for all three studies, in the sequence $80{ }^{\circ} \mathrm{C}, 160{ }^{\circ} \mathrm{C}$, and $120^{\circ} \mathrm{C}$, meaning the surface was already coated with $\mathrm{SnS}$ in the latter two studies.

Table 1. The average mass gain $\left(\Delta \mathrm{m}_{1}\right)$ and mass loss $\left(\Delta \mathrm{m}_{2}\right)$ resulting from the exposure of 1 and $\mathrm{H}_{2} \mathrm{~S}$ respectively and the ratio of the mass loss to the mass gain, $\left(\Delta \mathrm{m}_{2} / \Delta \mathrm{m}_{1}\right)$ at 80,120 , and $160{ }^{\circ} \mathrm{C}$

\begin{tabular}{|l|l|l|l|c|}
\hline $\begin{array}{l}\text { Temp. } \\
\left({ }^{\circ} \mathrm{C}\right)\end{array}$ & $\begin{array}{l}\Delta \mathrm{m}_{1} \\
\left(\mathrm{ng} / \mathrm{cm}^{2}\right)\end{array}$ & $\begin{array}{l}\Delta \mathrm{m}_{2} \\
\left(\mathrm{ng} / \mathrm{cm}^{2}\right)\end{array}$ & $\Delta \mathrm{m}_{2} / \Delta \mathrm{m}_{1}$ & $\begin{array}{l}\Delta \mathrm{m}_{1}+\Delta \mathrm{m}_{2} \\
\left(\mathrm{ng} / \mathrm{cm}^{2}\right)\end{array}$ \\
\hline 80 & $54 \pm 1$ & $-10 \pm 1$ & $-0.19 \pm 0.02$ & $44 \pm 1$ \\
\hline 120 & $44 \pm 1$ & $-12 \pm 1$ & $-0.27 \pm 0.03$ & $32 \pm 1$ \\
\hline 160 & $38 \pm 1$ & $-12 \pm 1$ & $-0.32 \pm 0.03$ & $26 \pm 1$ \\
\hline
\end{tabular}

Table 1 shows that the mass gain after exposure of $\mathbf{1}$ and the $\mathrm{N}_{2}$ purge $\left(\Delta \mathrm{m}_{1}\right)$, averaged over 3-5 cycles taken from the middle of a set of 100 cycles, decreases as temperature increases. Meanwhile, the mass loss after $\mathrm{H}_{2} \mathrm{~S}$ exposure and $N_{2}$ purge $\left(\Delta m_{2}\right)$ stays nearly constant. Therefore, the ratio of these values becomes more negative as the temperature increases, from $-0.19 \pm 0.02$ at $80{ }^{\circ} \mathrm{C}$ to $-0.32 \pm 0.03$ at $160{ }^{\circ} \mathrm{C}$. The negative value of $\Delta \mathrm{m}_{2}$ means that formamidinate ligand on $\mathrm{Sn}$ is replaced by a thiol and leaves the surface in the form of the free formamidine, resulting in mass loss in the second portion of the ALD cycle. An unusual positive value of $\left(\Delta \mathrm{m}_{2}\right)$ was reported recently in NiS ALD using $\operatorname{bis}\left(N, N^{\prime}\right.$-di-tert-butylacetamidinato)nickel(II). ${ }^{43}$ In those experiments, the positive value of $\Delta \mathrm{m}_{2}$ was attributed to the formation of an acid-base complex of the acetamidine ligand with a surface-bound thiol. Even at $200{ }^{\circ} \mathrm{C}$, the putative acid-base adduct inhibits further ALD reactions by site-blocking, contributing to a low growth rate of 0.15 $\AA /$ cycle. This interesting result cannot be applicable to the present case, though, because we measure a more typical negative value for $\Delta m_{2}$, and have higher growth per cycle at all temperatures.

The simplified model in figure 5 can help interpret these results. Although many other reactions can be invoked (as shown in Figure S2), if we constrain the considered reactions to the set that involves known, well-characterized gas-phase species and no ligand degradation, the set in figure 5 is complete (when reactions such as $2 \mathrm{~B} \rightarrow \mathrm{A}+\mathrm{E}$ $+\mathbf{1}$ are included). If the surface reactions were merely a linear combination of the $\mathrm{A} \rightarrow \mathrm{B} \rightarrow \mathrm{C}$ and $\mathrm{A} \rightarrow \mathrm{E} \rightarrow \mathrm{C}$ mechanisms, then the fraction representing the canonical $\mathrm{ABC}$ reaction could be inferred; it would be $54 \%$ at $80{ }^{\circ} \mathrm{C}$, increasing to $82 \%$ at $160{ }^{\circ} \mathrm{C}$ (for details of this calculation, see the Supporting Information). However, if only these two reaction sequences occurred, the total mass change per cycle $\left(\Delta \mathrm{m}_{1}\right.$ $+\Delta \mathrm{m}_{2}$ ) would remain constant because the final surface reaction product is the same (i.e., $\mathrm{C}$ ) in both the $\mathrm{A} \rightarrow \mathrm{B} \rightarrow \mathrm{C}$ 
and $\mathrm{A} \rightarrow \mathrm{E} \rightarrow \mathrm{C}$ mechanisms. If the reactions did not fully regenerate $C$, the growth per cycle during a deposition would not be constant, in contrast to Figure 6. Therefore, although the QCM experiments indicate a change in the surface reactions, the decrease in growth per cycle is not dictated by an $\mathrm{ABC}$ to AEC change alone.

Table 2. The average mass gain $\left(\Delta \mathrm{m}_{1}\right)$ and mass loss $\left(\Delta \mathrm{m}_{2}\right)$ resulting from the exposure of $\mathbf{1}$ and $\mathrm{H}_{2} \mathrm{~S}$ respectively and the ratio of the mass loss to the mass gain, $\left(\Delta \mathrm{m}_{2} / \Delta \mathrm{m}_{1}\right)$ at $120^{\circ} \mathrm{C}$, using the same recipe as before, but with changes to the exposure time of $\mathbf{1}$ and the length of the $\mathrm{N}_{2}$ purge.

\begin{tabular}{|l|l|l|l|l|}
\hline $\begin{array}{l}\text { Exposure, } \\
\text { Purge (s, s) }\end{array}$ & $\begin{array}{l}\Delta \mathrm{m}_{1} \\
\left(\mathrm{ng} / \mathrm{cm}^{2}\right)\end{array}$ & $\begin{array}{l}\Delta \mathrm{m}_{2} \\
\left(\mathrm{ng} / \mathrm{cm}^{2}\right)\end{array}$ & $\Delta \mathrm{m}_{2} / \Delta \mathrm{m}_{1}$ & $\begin{array}{l}\Delta \mathrm{m}_{1}+\Delta \mathrm{m}_{2} \\
\left(\mathrm{ng} / \mathrm{cm}^{2}\right)\end{array}$ \\
\hline 4,30 & $44 \pm 1$ & $-12 \pm 1$ & $-0.27 \pm 0.03$ & $32 \pm 1$ \\
\hline 11,30 & $43 \pm 1$ & $-11 \pm 1$ & $-0.26 \pm 0.03$ & $32 \pm 1$ \\
\hline 11,60 & $42 \pm 1$ & $-10 \pm 1$ & $-0.24 \pm 0.03$ & $32 \pm 1$ \\
\hline 11,90 & $39 \pm 1$ & $-7 \pm 1$ & $-0.18 \pm 0.03$ & $32 \pm 1$ \\
\hline 31,60 & $39 \pm 1$ & $-8 \pm 1$ & $-0.21 \pm 0.03$ & $31 \pm 1$ \\
\hline 61,60 & $31 \pm 1$ & $-1 \pm 1$ & $-0.03 \pm 0.03$ & $30 \pm 1$ \\
\hline
\end{tabular}

Some more insight can be gleaned from additional QCM studies at $120{ }^{\circ} \mathrm{C}$ using altered ALD recipes. In the first series, the exposure time of $\mathbf{1}$ was held constant at $11 \mathrm{~s}$ (increased from $4 \mathrm{~s}$ ) and the purge time was varied between 30,60, and $90 \mathrm{~s}$ (vs. $30 \mathrm{~s}$ ). In the second series, the exposure time of 1 was increased to 11, 31, or $61 \mathrm{~s}$ with a fixed purge time of $60 \mathrm{~s}$. Table 2 displays the results. We first note that the total mass change per cycle remains nearly constant regardless of the exposure or purging. Despite this constant value of $\Delta \mathrm{m}_{2}+\Delta \mathrm{m}_{1}$, the surface chemistry does appear to be changing considerably, as assessed by the ratio $\Delta \mathrm{m}_{2} / \Delta \mathrm{m}_{1}$, which ranges from -0.27 to -0.03 . These facts suggest using mechanisms ABC and AEC again would be appropriate; doing so, this range of ratios represents a change from $70 \% \mathrm{ABC}$ to just $30 \% \mathrm{ABC}$.

Comparing the entries in the series at constant exposure time (11 s) reveals that the fraction of mechanism ABC can be decreased modestly with increased purge time, but this change does not alter the total mass change per cycle. Presumably what happens during the purging, when $\mathrm{N}_{2}$ flows through the reactor while it is opened to the vacuum pump, is the combination of a surface thiol and a tin-bound surface formamidinate to eliminate formamidine, i.e., reaction $\mathrm{B} \rightarrow \mathrm{E}$ (figure 5). Because the $\Delta \mathrm{m}_{1}$ is measured after the $\mathrm{N}_{2}$ purge, the apparent mass gain is lessened; similarly, owing to the loss of some ligands during the purge, fewer ligands are present on the surface at $\mathrm{H}_{2} \mathrm{~S}$ exposure, decreasing the mass loss in that step.

Comparing the entries in the series with varying exposure time reveals an even stronger trend in the same direction. Apparently, longer exposure of $\mathbf{1}$ increases the fraction either of reaction $\mathrm{A} \rightarrow \mathrm{E}$ or $\mathrm{B} \rightarrow \mathrm{E}$. This increase does not result in increased deposition of $\mathrm{SnS}$ - the longer exposure does not add more tin to the surface, but rather removes more formamidine ligand from the surface. This result can be rationalized in various ways; as one example, if gas-phase $\mathbf{1}$ is in equilibrium with chemisorbed tin monoformamidinate and gas-phase formamidine, then the monoformamidinate formed in $\mathrm{A} \rightarrow \mathrm{B}$ can then be desorbed by free formamidine, regenerating a surface thiol and $\mathbf{1}$ (i.e., $\mathrm{HL}+\mathrm{B} \rightarrow \mathrm{A}+\mathbf{1}$ ). The newly regenerated $\mathbf{1}$ (or the excess of 1 present in the gas phase) could then chemisorb via $\mathrm{A} \rightarrow \mathrm{E}$.

Alternatively, the data in table 2 can be viewed in light of the total length of a half-cycle (exposure plus purge time). As summarized in table S2, the longer the total half-cycle time, the greater the fraction of mechanism AEC. This result can be rationalized as resulting from the increase of time allowed for $\mathrm{B} \rightarrow \mathrm{E}$ or $\mathrm{A} \rightarrow \mathrm{E}$ to proceed. Because both pathways to E require more collisions than a single $A \rightarrow B$ reaction, it can be understood that the reactions generating $\mathrm{E}$ may be enhanced when the reaction time (total halfcycle time) is increased. Regardless of the exposure time, the highest fraction of AEC was obtained at the longest half-cycle time, increasing from $30 \%$ at $34 \mathrm{~s}(4+30 \mathrm{~s})$ to $70 \%$ at $121 \mathrm{~s}(61+60 \mathrm{~s})$. The increase is non-linear, however, suggesting that both the time used for the half-cycle of $\mathbf{1}$ and the exposure time of $\mathbf{1}$ play important roles in explaining the fraction of AEC.

While constructing table 2, time for both half-cycles was increased in the same fashion. Although the $\Delta \mathrm{m}_{2}$ does decrease as the purge time increases from $30 \mathrm{~s}$ to $90 \mathrm{~s}$, which could be consistent with an increase in reaction $\mathrm{C} \rightarrow \mathrm{F}$, the much larger effect results from increasing the exposure time from $4 \mathrm{~s}$ to $61 \mathrm{~s}$. However, increased $\mathrm{H}_{2} \mathrm{~S}$ exposure should, at least among the mechanisms in figure 5, merely provide more time to regenerate surface $C$. Taken together with little to no change in the total mass change per cycle as the time for the $\mathrm{H}_{2} \mathrm{~S}$ half cycle increases, we infer that the dominant changes in the surface chemistry do not happen during the $\mathrm{H}_{2} \mathrm{~S}$ half of the ALD cycle. It can also be concluded that the sequence $\mathrm{C} \rightarrow \mathrm{F}$ which reduces thiols available for reaction with $\mathbf{1}$ is largely independent of the time of the $\mathrm{H}_{2} \mathrm{~S}$ half cycle, that is, the number of available surface thiols is almost constant at a given temperature.

The total mass change per cycle does decrease slightly in the longest exposure; perhaps the dramatically increased fraction of $\mathrm{E}$ does not complete its second reaction step to regenerate $\mathrm{C}$ quite as efficiently upon exposure to $\mathrm{H}_{2} \mathrm{~S}$. Nonetheless, the QCM data provide strong evidence that the fraction of reactions generating $E$ is increasing from 36 to $70 \%$ with longer exposure of $\mathbf{1}$ (11 vs. $61 \mathrm{~s}$, both with 60 s purge; see tables 2, S2), without, however, much altering the amount of SnS deposited. The data therefore show that the kinetics of $\mathrm{E} \rightarrow \mathrm{C}$ do not play a major role in determining the total mass change (growth) per cycle.

In other words, at $120^{\circ} \mathrm{C}$, the $\mathrm{B} \rightarrow \mathrm{C}$ (canonical protonolysis of surface formamidinate by $\mathrm{H}_{2} \mathrm{~S}$ ) and $\mathrm{E} \rightarrow \mathrm{C}$ (insertion of $\mathrm{H}_{2} \mathrm{~S}$ into a surface $\mathrm{Sn}-\mathrm{S}$ bond) reactions regenerate the same density of surface thiols during the $\mathrm{H}_{2} \mathrm{~S}$ exposure regardless of the fraction of $\mathrm{E}$ on the surface. Therefore, the changing amount of SnS deposited at different temperatures is not explained by the fraction of sites proceeding through $\mathrm{E} \rightarrow \mathrm{C}$, as we have determined above, or by the extent to which $\mathrm{E} \rightarrow \mathrm{C}$ is completed. Indeed, if the reaction 
$\mathrm{E} \rightarrow \mathrm{C}$ were not fully completed in every cycle, the growth rate would decrease with increasing cycle number; instead, the growth per cycle remains constant at a given temperature. The growth per cycle also remains constant as the fraction of AEC increases at $120^{\circ} \mathrm{C}$.

We seem now to have ruled out both 1 reacting differently during its half of the cycle and $\mathrm{H}_{2} \mathrm{~S}$ reacting differently during its half. Nonetheless, as temperature increases, the growth per cycle certainly decreases. We must therefore locate an overlooked reaction, one that can both limit the amount of SnS deposited and be enhanced at higher temperatures. The latter condition implies that $\Delta S$ for this reaction should be positive.

Figure 5 contains just such a reaction: two thiols on the surface can disproportionate to form a bridging sulfide and evolve $\mathrm{H}_{2} \mathrm{~S}$. In one half of the ALD cycle, we label this reaction $\mathrm{A} \rightarrow \mathrm{D}$, and in the other half $\mathrm{C} \rightarrow \mathrm{F}$. The entropy change of this reaction will be positive-a molecule of gas is freed from a surface. Furthermore, this reaction, unlike $\mathrm{ABC} / \mathrm{AEC}$, would allow for a temperature-dependent decrease in growth per cycle, if its extent were temperature controlled. The decrease in SnS growth per cycle as temperature increases is therefore likely to be a result of reaction $\mathrm{A} \rightarrow \mathrm{D}$ or $\mathrm{C} \rightarrow \mathrm{F}$ increasing. This increase yields a lower number of surface thiols available to react with $\mathbf{1}$ as temperature increases. We have not, however, observed these reactions directly.

Although these QCM data may not allow us to deduce the origin of the decreasing growth per cycle, they are strongly suggestive. By drawing on the crystallographic radius of the formamidinate ligand when bound to calcium(II), 0.42 $\mathrm{nm},{ }^{31}$ we can estimate the maximum growth per cycle if the ALD reaction were limited by the steric demand of the surface-bound ligand. ${ }^{42}$ Using the standard assumption that $\theta_{\max } \leq 0.7,{ }^{42}$ the maximum growth per cycle is 0.55 $\AA$ /cycle-significantly below the observed value of 0.86 $\AA /$ cycle. In light of the QCM data, we interpret the higher growth per cycle at $80{ }^{\circ} \mathrm{C}$ as resulting from the fraction of reactions generating $\mathrm{E}$, which naturally does not have the same steric constraint as B because both ligands have been removed from the surface already. The high reactivity of $\mathbf{1}$ therefore allows it to partially bypass the limitations of ligand steric congestion, using reactions $\mathrm{A} \rightarrow \mathrm{E}$ and $\mathrm{B} \rightarrow \mathrm{E}$ to eliminate formamidinate ligands from the congested surface. These reactions make additional thiols available for reaction with $\mathbf{1}$ that would have been shadowed by formamidinate ligands, enhancing the $\mathrm{SnS}$ growth per cycle.

As is mentioned above, the fraction of reactions proceeding through $\mathrm{AEC}$ at $80^{\circ} \mathrm{C}(46 \%)$ is significantly higher than at $160{ }^{\circ} \mathrm{C}(18 \%)$. Because the growth per cycle at $80{ }^{\circ} \mathrm{C}$ exceeds the theoretical maximum for reaction $\mathrm{ABC}$, it is very likely that the higher fraction of AEC reactions at lower temperature contributes to the higher growth per cycle. Interestingly, because both reactions $\mathrm{A} \rightarrow \mathrm{E}$ and $\mathrm{B} \rightarrow \mathrm{E}$ should have positive $\Delta S$, we might expect them to become even more favorable at higher temperature. However, in contrast with reaction $\mathrm{A} \rightarrow \mathrm{B}$, both $\mathrm{A} \rightarrow \mathrm{E}$ and $\mathrm{B} \rightarrow \mathrm{E}$ require that the distance between two thiols is small enough for the reaction to proceed (and also that the precursor complex is reactive enough toward two thiols for it to perform them). The higher extent of these reactions at lower temperatures provides strong, albeit indirect, evidence for a decreased density of surface thiols at higher temperature.

Together, the ALD and QCM results imply that the equilibrium surface coverage of thiol groups determines the growth per cycle at a given temperature. The surface chemistry shifts, in the limits of lower temperatures and longer purge and especially exposure times, toward the non-canonical reactions generating $E$ from the canonical reaction generating $\mathrm{B}$. However, at a single temperature, the growth per cycle remains essentially constant. Therefore, the growth per cycle decreasing as temperature increases suggests control by an equilibrium that depletes the surface of reactive sites, and is entropically favored. The reaction $\mathrm{C} \rightarrow \mathrm{F}$ meets both of these requirements. We point out here that $\mathrm{E}$ and $\mathrm{F}$ are actually structural isomers. Therefore, it is not strictly necessary for the surface to follow $\mathrm{E} \rightarrow \mathrm{C} \rightarrow \mathrm{F}$; some fraction of the surface can directly isomerize $\mathrm{E} \leftrightarrow \mathrm{F}$ during regeneration of the temperature-controlled equilibrium thiol coverage in the presence of $\mathrm{H}_{2} \mathrm{~S}$.

This conclusion provides us with an intriguing proposal: more reactive precursors, such as $\mathbf{1}$ and 2, allow for a very high ALD growth per cycle at low temperature by utilizing reaction $\mathrm{A} \rightarrow \mathrm{E}$ (or $\mathrm{B} \rightarrow \mathrm{E}$ ) to circumvent the limitations of steric congestion on the surface. This same reactivity, however, cannot overcome a temperature-dependent equilibrium concentration of surface thiols, and thereby gives rise to a strong temperature dependence of the growth per cycle.

\subsection{Properties of the $\mathrm{SnS}$ films.}

A SnS film (580 nm thick, 7500 cycles) deposited at a low substrate temperature of $80{ }^{\circ} \mathrm{C}$ (Figure S4) was annealed at $400{ }^{\circ} \mathrm{C}$ under 10 Torr of $2.5 \% \mathrm{H}_{2} \mathrm{~S}$ for 60 minutes. Delamination of this $\mathrm{SnS}$ film was observed in several spots as shown in figure S4. Considering the nucleation period shown by the early cycles of the QCM data (Figure $6 a)$, we explored whether the delamination might be determined by the early stages of growth. Indeed, we were able to prepare well-adhered films by changing the deposition recipe during the initial cycles of deposition. A longer purging time (30 s) and longer evacuation time (30 s) were used compared to those used for obtaining the plot of growth per cycle vs. temperature (figure 3, where both times were $10 \mathrm{~s}$ ). The longer purging and evacuation times were used for the first 500 cycles, and then the original times (both $10 \mathrm{~s}$ ) were used to save deposition time for the remaining 7000 cycles. The resulting $\mathrm{SnS}$ film grown on thermal oxide at $80{ }^{\circ} \mathrm{C}$ was annealed at $400{ }^{\circ} \mathrm{C}$ under $2.5 \%$ $\mathrm{H}_{2} \mathrm{~S}$. No delamination of this film was observed after annealing (figure S5).

SnS films grown at a higher substrate temperature of $120{ }^{\circ} \mathrm{C}$ using the standard purging and evacuation times (both $10 \mathrm{~s}$ ) were not observed to delaminate after annealing at $400{ }^{\circ} \mathrm{C}$. 


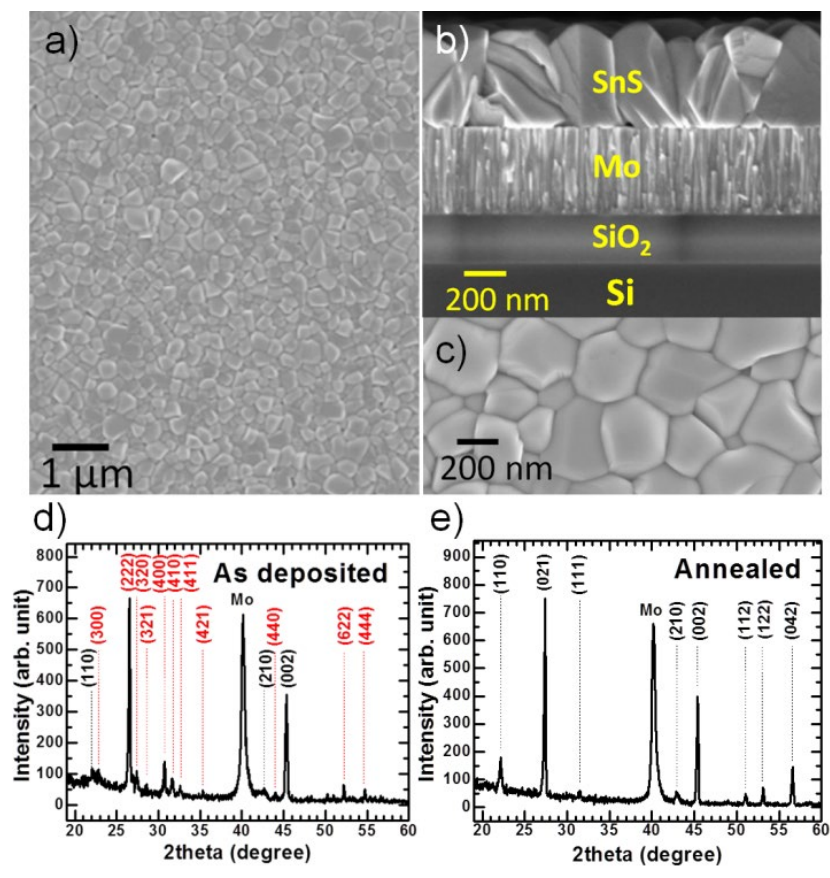

Figure 7. SEM images of an annealed SnS film grown (7500 cycles) at $80{ }^{\circ} \mathrm{C}$ on a sputtered molybdenum film on thermal oxide and XRD spectra of as-deposited (before annealing) \& annealed films; a) top view image, b) cross sectional image, c) enlarged image of a), and XRD spectrum (red Miller indices: cubic, black Miller indices: orthorhombic) of d) as-deposited film, e) annealed film. The reflections are assigned based on JCPDS N0. 39-0354 for orthorhombic-SnS ${ }^{3}$ and Nair et al. ${ }^{44}$ for cubic-SnS.

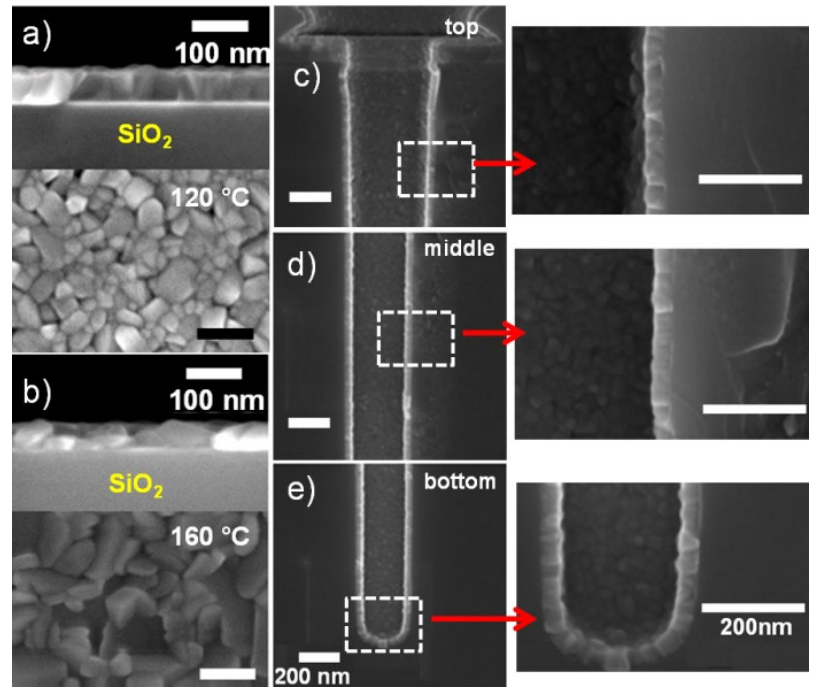

Figure 8. Top view and cross-sectional SEM image of SnS ALD films grown on a thermal oxide at a) 120 and b) $160{ }^{\circ} \mathrm{C}$ and cross-sectional SEM images of a hole with aspect ratio of 25:1 coated with SnS film (750 ALD cycles) grown at $120^{\circ} \mathrm{C}$; c) top, d) middle, and e) bottom.

Figure 7 shows SEM images and XRD spectra of the annealed $\mathrm{SnS}$ film grown at $80{ }^{\circ} \mathrm{C}$ on a sputtered molybdenum film on thermal oxide using $30 \mathrm{~s}$ purging and $30 \mathrm{~s}$ evacuation. On both silicon oxide (Figure S5) and molyb- denum, the SnS film grown at $80{ }^{\circ} \mathrm{C}$ contains two phases, cubic (Miller indices marked in red) and orthorhombic (black Miller indices). XRD shows that the film grown on molybdenum (Figure $7 \mathrm{~d}$ ) is more highly oriented compared to that on thermal oxide (Figure S5d): on Mo, the (222) reflection dominates the cubic peaks, whereas on thermal oxide, the (222) and (400) reflections are both strong. On both substrates, the as-deposited films show the (002) peak of the orthorhombic phase, and this peak and the (021) peak dominate both XRD patterns after annealing. Because the orientations differ between substrates, and are different from those reported for other precursors, these results are consistent with both substrate and precursor effects on the crystallinity and orientation of the asdeposited and annealed films. For example, in SnS ALD using $2^{5}$ and $\mathrm{H}_{2} \mathrm{~S}$, the as-deposited film was primarily cubic and the annealed, orthorhombic film had preferred orientations of (021) and (111). ${ }^{5}$

Figures $\mathrm{S} 4 \mathrm{~b}\left(80^{\circ} \mathrm{C}\right), 8 \mathrm{a}\left(120^{\circ} \mathrm{C}\right)$, and $8 \mathrm{~b}\left(160^{\circ} \mathrm{C}\right)$ show that the grain size of polycrystalline $\mathrm{SnS}$ film on thermal oxide increases with increasing temperature as shown in other ALD processes for SnS using 2 and 3.1,3,5 Figures 8ce show cross-sectional SEM images of SnS deposited at $120{ }^{\circ} \mathrm{C}$ inside a deep hole with an aspect ratio of $\sim 25: 1$. The images show a uniform, conformal coating indicating self-limiting ALD reactions. ${ }^{1}$
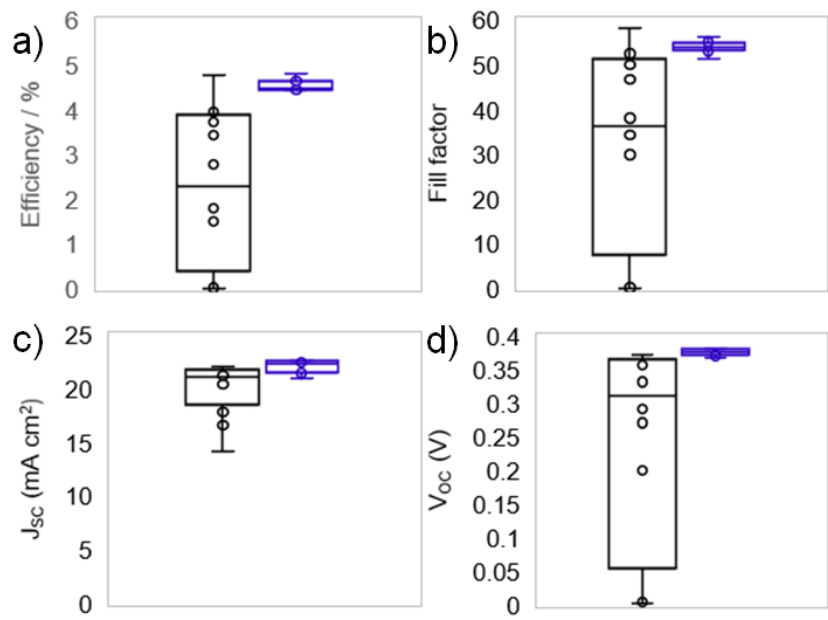

Figure 9. Key performance characteristics of SnS photovoltaic devices prepared using 3 (left, black) and $\mathbf{1}$ (right, blue); a) efficiency, b) fill factor, c) short-circuit current, and d) open circuit voltage.

Solar cells were prepared as described previously, ${ }^{4,30}$ using 1 and 3. Performance characteristics of photovoltaic devices under AM1.5 illumination are presented in Figure 9, using as the absorber ca. $700 \mathrm{~nm}$ of $\mathrm{SnS}$ deposited either from 1 at $120{ }^{\circ} \mathrm{C}$ (12 cells) or from 3 at $200{ }^{\circ} \mathrm{C}$ (12 cells). The best cell using 1 showed higher open-circuit voltage ( $V_{\text {oc }}$ ) and short-circuit current (Jsc), but slightly lower fill factor than the best device using $\mathbf{3}$, leading to similar efficiencies. However, as is clear from figure 9, the consistency of performance in every metric was significantly improved using 1. The highly reactive 1 enables high-quality $\mathrm{SnS}$ to be deposited at lower temperatures with denser nuclea- 
tion and a more conformal coverage, which persisted even after annealing during solar cell fabrication.

\section{Conclusion}

We synthesized a new highly volatile liquid tin(II) precursor, bis( $N, N^{\prime}$-diisopropylformamidinato)tin(II) (1 in scheme 1), useful for ALD. As a liquid precursor it has the advantage of providing a consistent vapor pressure, resulting in reproducible ALD for the entire lifetime of a precursor charge, compared to solids in which changing surface area can alter the vaporization kinetics. It was found that the growth rate of SnS ALD using 1 and $\mathrm{H}_{2} \mathrm{~S}$ decreases linearly from 0.86 to $0.3 \AA$ /cycle with increasing substrate temperature in the range of $65-200{ }^{\circ} \mathrm{C}$. The highest growth rate for SnS ALD using 1, $0.86 \AA$ /cycle, is much higher than that using other reported liquid tin(II) precursors such as Sn(acac)2 (4, highest growth rate: $0.24 \AA$ Acycle) and Sn(dmamp $)_{2}$ (5, highest growth rate: $0.45 \AA$ Acycle). Based on QCM studies and plausible surface reactions, an explanation of the linear decrease of the growth rate was proposed. It appears that the decrease of the growth rate mainly depends on the areal density of thiol groups, which varies with temperature. Interesting changes in the mechanism of chemisorption of $\mathbf{1}$ were observed by QCM, depending on temperature, exposure time, and purge time, but these changes did not impact the growth per cycle of the ALD process, except as they mediate equilibration of the thiol concentration. We successfully deposited SnS films on thermal oxide and sputtered molybdenum films at $80^{\circ} \mathrm{C}$, which are not delaminated even after they were annealed at $400{ }^{\circ} \mathrm{C}$ under $\mathrm{H}_{2} \mathrm{~S}$, by increasing time for purging and evacuation. The polycrystalline SnS films grown at $80{ }^{\circ} \mathrm{C}$ contain both cubic and orthorhombic phases. After annealing, all cubic phase disappeared from the films, resulting in pure orthorhombic SnS polycrystalline films which are highly oriented in the (021) and (002) directions, an unusual pair of orientations to obtain. ${ }^{3,5}, 9$ Photovoltaic devices prepared from these annealed films grown at $120{ }^{\circ} \mathrm{C}$ perform as well as the best devices prepared from 3 , and demonstrate significantly enhanced uniformity in their J-V properties and device yield.

\section{Experimental Section}

\subsection{Synthesis}

All operations were carried out in vacuum or under argon with standard Schlenk and glovebox techniques. $N, N^{\prime}-$ diisopropylcarbodiimide (99\%), triethylsilane (99\%), methanol (anhydrous, 99.8\%), palladium(II) chloride (anhydrous, $60 \% \mathrm{Pd}$ basis), methyllithium solution (1.6 M in diethyl ether), pentane (anhydrous), tin(II) chloride ( $\geq 99.99 \%$ trace metal basis) and diethyl ether (anhydrous) were purchased from Sigma-Aldrich. Solvents were degassed with argon and dried by passage through an alumina column (Innovative Technology, Inc., Amesbury, MA). All other chemicals were used as received. $N, N^{\prime}$ diisopropylformamidine was prepared by a literature route. ${ }^{45}$

$\operatorname{Bis}\left(N, N^{\prime}\right.$-diisopropylformamidinato)tin(II), 1. Methyllithium solution (200 mL of $1.6 \mathrm{M}, 320 \mathrm{mmol}$ ) was added dropwise to a diethyl ether solution (250 mL) of $N, N^{\prime}$ - diisopropylformamidine (37.27 g, $1056 \mathrm{mmol}$ ) in a Schlenk flask $(500 \mathrm{~mL})$ on an ice bath under an argon atmosphere. The ice bath was removed after the addition was complete. The solution was stirred for an hour. The resulting lithium amidinate solution was transferred via cannula to an addition funnel connected to a Schlenk flask (1000 mL) containing $\mathrm{SnCl}_{2}$ (16.72 g, $88.2 \mathrm{mmol}$ ) and diethyl ether (400 $\mathrm{mL})$ cooled with a dry ice-acetone bath $\left(-78^{\circ} \mathrm{C}\right)$. Using an addition funnel, the lithium amidinate was added dropwise to $\mathrm{SnCl}_{2}$ in diethyl ether over a period of $1 \mathrm{~h}$ under Ar flow. After 10 minutes, the reaction mixture was allowed to warm, and was stirred at room temperature overnight (ca. $16 \mathrm{~h}$ ). Volatiles were removed in an ice bath under reduced pressure and the oily residue was dissolved in pentane (ca. $450 \mathrm{~mL}$ ). The solution was filtered through Celite and the liquid residue was washed with pentane under Ar. In an ice bath, the filtrate was concentrated under vacuum to obtain a colorless liquid. This liquid was heated at $100{ }^{\circ} \mathrm{C}$ for $1 \mathrm{~h}$ under $\mathrm{Ar}$ and a distillation apparatus attached to the Schlenk flask. Distillation was performed twice under vacuum (0.1 Torr), at different bath temperatures, maintaining a drip rate of ca. 1 drop / 2 s (first distillation: room temp. to remove organic volatiles; second: $55-60{ }^{\circ} \mathrm{C}$ ) to afford an oily liquid, compound 1. Yield: $22.38 \mathrm{~g}(68 \%)$. Anal. Calcd. for $\mathrm{C}_{14} \mathrm{H}_{30} \mathrm{~N}_{4} \mathrm{Sn}: \mathrm{C}, 45.1 ; \mathrm{H}, 8.10 ; \mathrm{N}, 15.0$. Found: $\mathrm{C}, 44.8 ; \mathrm{H}, 7.97 ; \mathrm{N}, 14.5 .{ }^{1} \mathrm{H}$ NMR $\left(25{ }^{\circ} \mathrm{C}, \mathrm{C}_{6} \mathrm{D}_{6}, 500 \mathrm{MHz}\right): \delta$ 8.17 (84\%: s; 16\%: d, $J 117 / 119_{S n}=38 \mathrm{~Hz} ; 2 \mathrm{H}$ ), 3.44 (septet, $J$ $=6.4 \mathrm{~Hz}, 4 \mathrm{H}), 1.18(\mathrm{~d}, J=6.5 \mathrm{~Hz}, 24 \mathrm{H}) .{ }^{13} \mathrm{C} \mathrm{NMR}\left(25{ }^{\circ} \mathrm{C}\right.$, $\mathrm{C}_{6} \mathrm{D}_{6}, 500 \mathrm{MHz}$ ): $\delta 159.8$ (1 C), 51.2 (2 C), 26.1 (4 C).

\subsection{Atomic Layer Deposition of $\mathrm{SnS}$}

SnS thin films were deposited on thermally wet-oxidized silicon substrates $\left(300 \mathrm{~nm}\right.$ of $\mathrm{SiO}_{2}$ on $\mathrm{Si}$ ) by atomic layer deposition (ALD) in a custom-built hot-wall ALD reactor from the reaction of 1 with $4 \% \mathrm{H}_{2} \mathrm{~S}$ in $\mathrm{N}_{2}$ (Airgas). Films were also deposited on silicon trenches with an aspect ratio of 25:1 obtained by reactive ion etching, in order to confirm step coverage. The growth temperature was between 65 and $200{ }^{\circ} \mathrm{C}$. The source temperature was kept at $65{ }^{\circ} \mathrm{C}$ for 1 . Tin precursor (1) vapors assisted by $\mathrm{N}_{2}$ and $4 \%$ $\mathrm{H}_{2} \mathrm{~S}$ in $\mathrm{N}_{2}$ were injected sequentially into the deposition chamber to allow chemical reactions to occur successively on the substrate surface. One dose of 1 and one dose of $\mathrm{H}_{2} \mathrm{~S}$ were used in each cycle, based on initial studies showing saturation behavior under these dosing conditions. The dosing time was $1 \mathrm{~s}$ for both $\mathbf{1}$ in $\mathrm{N}_{2}$ and $\mathrm{H}_{2} \mathrm{~S}$. Each dose of $\mathbf{1}$ delivers 10 Torr and each dose of $\mathrm{H}_{2} \mathrm{~S}$ delivers 3 Torr of total pressure to the reactor. Both 1 in $\mathrm{N}_{2}$ and $\mathrm{H}_{2} \mathrm{~S}$ were held in the reactor for $3 \mathrm{~s}$ after dosing is finished, unless otherwise stated. Purging with a flow of $\mathrm{N}_{2}$ at reduced pressure (ca. 3 Torr) after each dose of precursor vapor was performed to remove unreacted precursor and byproduct species, and to prevent reactions in the vapor phase. Different purging times were used for different experiments; a typical recipe after each chemical was $10 \mathrm{~s}$ of purging with $\mathrm{N}_{2}$ followed by $10 \mathrm{~s}$ of evacuation (opened to vacuum without $\mathrm{N}_{2}$ ). For the ALD using 1, 3500 or 7500 cycles between 65 and $200{ }^{\circ} \mathrm{C}$ are used. The deposition process was done using stop-flow ALD mode. 


\subsection{Characterization}

Elemental analyses were performed by the University of Illinois School of Chemical Sciences Microanalysis Laboratory (Urbana, IL). Nuclear Magnetic Resonance spectra were obtained in the Harvard University Laukien-Purcell Instrumentation Center on a Varian Unity INOVA $500 \mathrm{MHz}$ spectrometer at $11.7 \mathrm{~T}$. TGA experiments were performed with a TA Instruments Model Q50 system in a glovebox. $\mathrm{N}_{2}$ was used as the flow gas (balance gas: $40 \mathrm{~mL} / \mathrm{min}$, sample gas: $40 \mathrm{~mL} / \mathrm{min})$. Aluminum sample pans $(100 \mu \mathrm{L}$, TA Instruments Cat. \#: 952323.902) with diameter $1 \mathrm{~cm}$ were used for this experiment; a new pan was used for each experiment. Morphology of the films was examined by field emission scanning electron microscopy (FESEM, Supra55VP). X-ray Photoelectron Spectroscopy (XPS, Thermo Scientific K-Alpha) was used to characterize the composition of the SnS films. Argon ion sputtering of $30 \mathrm{~s}$ at $500 \mathrm{eV}$ was used to clean the surface oxide or carbon prior to XPS composition measurements. Survey scans were performed on films grown at various temperatures, and the spectra were analyzed using the Thermo Avantage software to obtain compositions. High resolution X-ray diffraction (HRXRD, PANalytical X'Pert Pro) $(\lambda=1.542 \AA$ ) $\theta-2 \theta$ scans were performed.

\subsection{Quartz Crystal Microbalance (QCM) studies}

To understand the surface reaction mechanism at different deposition temperatures, the mass change during several cycles of ALD was investigated using an in situ QCM at three different temperatures. Surface chemistry was identified by observing the ratio $\Delta \mathrm{m}_{2} / \Delta \mathrm{m}_{1}$, where $\Delta \mathrm{m}_{1}$ is the mass change (usually positive) resulting from the surface reaction after the exposure of $\mathbf{1}$ and purging, and $\Delta \mathrm{m}_{2}$ is the mass change (usually negative) resulting from the surface reaction after the exposure of $\mathrm{H}_{2} \mathrm{~S}$ and purging. Molybdenum $(500 \mathrm{~nm})$ was sputtered onto the gold-covered quartz crystal surface prior to the experiment to simulate real growth conditions for a solar cell. The experiments were done on the same crystal in the order of $80^{\circ} \mathrm{C}, 160^{\circ} \mathrm{C}$, and $120^{\circ} \mathrm{C}$. A pulse sequence of 1 dosing (1 s) $\rightarrow$ exposure (3 s) $\rightarrow \mathrm{N}_{2}$ purging (30 s) $\rightarrow$ vacuum (10 s) $\rightarrow \mathrm{H}_{2} \mathrm{~S}$ dosing $(1 \mathrm{~s}) \rightarrow$ exposure (3s) $\rightarrow \mathrm{N}_{2}$ purging (30 s) $\rightarrow$ vacuum (10 s) was used. In additional experiments at $120{ }^{\circ} \mathrm{C}$, the exposure time of 1 was varied between $10 \mathrm{~s}$ and $60 \mathrm{~s}$ with no other changes. Finally, the purging time was varied between $30 \mathrm{~s}$ and $90 \mathrm{~s}$ with the exposure time held at $10 \mathrm{~s}$. Note that due to the high surface roughness of the quartz crystal and its sensitivity to temperature, the mass readings of QCM (in $\mathrm{ng} / \mathrm{cm}^{2}$ ) were calibrated against the growth rate of $\mathrm{SnS}$ on thermal oxide substrates at their respective temperatures. The calibration factors (growth rate calculated from QCM measurement / growth rate calculated from SEM measurement) were 1.88 at $80^{\circ} \mathrm{C}, 1.94$ at $120^{\circ} \mathrm{C}$ and 2.26 at $160^{\circ} \mathrm{C}$ ) Because this calibration is a linear scaling, it will not impact the ratio of $\Delta \mathrm{m}_{2} / \Delta \mathrm{m}_{1}$ nor the subsequent conclusions based on it.

\subsection{Photovoltaic device fabrication and testing}

Solar cell devices were fabricated using $720 \mathrm{~nm}$ of SnS films deposited at $120{ }^{\circ} \mathrm{C}$ from 1 on thermal oxide substrate coated with molybdenum by $\mathrm{RF}$ sputtering. The films were annealed in $\mathrm{H}_{2} \mathrm{~S}$ for 1 hour in the same reactor chamber after deposition and then subjected to 24 hours of ambient air exposure for passivation by a thin layer of $\mathrm{SnO}_{x}$. The n-type layers were then applied, using nitrogendoped $\mathrm{Zn}(0, \mathrm{~S})$ deposited by ALD, followed by indium tin oxide (ITO) deposited by RF sputtering. Front contact was deposited using $500 \mathrm{~nm}$ of thermally evaporated Ag. A more detailed description of the fabrication procedure and properties of each layer (excepting the $\mathrm{SnS}$ absorber) can be found in previous papers. ${ }^{4,30}$ On a $1 \mathrm{in}^{2}$ sample, 12 devices were fabricated with an active area of $0.24 \mathrm{~cm}^{2}$ each. The current-voltage $(\mathrm{J}-\mathrm{V})$ characteristics were measured using Agilent 4156C and Keithley 2400 semiconductor characterization systems under $100 \mathrm{~mW} / \mathrm{cm}^{2}$ AM $1.5 \mathrm{G}$ illumination. The key performance characteristics were then compared to those of the devices fabricated using $\mathrm{SnS}$ films deposited from 3 of the same thickness at $200{ }^{\circ} \mathrm{C}$, which was previously reported as the optimal deposition temperature for that precursor. ${ }^{4,30}$

\section{ASSOCIATED CONTENT}

Supporting Information. Mechanism details, XPS (X-ray Photoelectron Spectroscopy) spectra, SEM images and XRD diffractogram of SnS film grown on thermal oxide. This material is available free of charge via the Internet at http://pubs.acs.org.

\section{AUTHOR INFORMATION}

\section{Corresponding Author \\ *gordon@chemistry.harvard.edu.}

\section{Present Addresses}

\# Center for Educational Research, Seoul National University, 1 Gwanak-ro, Gwanak-gu, Seoul 08826, Korea.

† LAM Research, 1 Portola Avenue, Livermore, CA 94551, USA. $\S$ Department of Chemistry, Tufts University, 62 Talbot Avenue, Medford, MA 02155, USA.

‡ LAM Research, 11361 SW Leveton Drive, Tualatin, OR 97062, USA.

ə Applied Materials, Inc., 3050 Bowers Avenue, Santa Clara, CA 95054, USA.

\section{ACKNOWLEDGMENT}

This work was supported in part by the Center for the Next Generation of Materials by Design, an Energy Frontier Research Center funded by the U.S. DOE, Office of Science. Portions of this study were performed at the Center for Nanoscale Systems (CNS) at Harvard University, a member of the National Nanotechnology Infrastructure Network (NNIN), which is supported by the National Science Foundation under NSF award no. ECS-0335765. We are grateful to Prof. Tonio Buonassisi (MIT) for kindly providing access to the solar simulator used in these experiments. 


\section{REFERENCES}

(1) Kim, S. B.; Sinsermsuksakul, P.; Hock, A. S.; Pike, R. D.; Gordon, R. G., Synthesis of N-Heterocyclic Stannylene (Sn(II)) and Germylene (Ge(II)) and a Sn(II) Amidinate and Their Application as Precursors for Atomic Layer Deposition. Chem. Mater. 2014, 26, 3065-3073.

(2) Kim, J. Y.; George, S. M., Tin Monosulfide Thin Films Grown by Atomic Layer Deposition Using Tin 2,4-Pentanedionate and Hydrogen Sulfide. J. Phys. Chem. C 2010, 114,, 17597-17603.

(3) Sinsermsuksakul, P.; Heo, J.; Noh, W.; Hock, A. S.; Gordon, R. G., Atomic Layer Deposition of Tin Monosulfide Thin Films. Adv. Ener. Mater. 2011, 1, 1116-1125.

(4) Sinsermsuksakul, P.; Sun, L.; Lee, S. W.; Park, H. H.; Kim, S. B.; Yang, C.; Gordon, R. G., Overcoming Efficiency Limitations of SnS-Based Solar Cells. Adv. Ener. Mater. 2014, 4, 1400496/11400496/7.

(5) Park, H. H.; Heasley, R.; Sun, L.; Steinmann, V.; Jaramillo, R.; Hartman, K.; Chakraborty, R.; Sinsermsuksakul, P.; Chua, D.; Buonassisi, T.; Gordon, R. G., Co-optimization of SnS absorber and $\mathrm{Zn}(\mathrm{O}, \mathrm{S})$ buffer materials for improved solar cells. Prog. Photovolt.: Rese.. Appl. 2015, 23, 901-908.

(6) Sinsermsuksakul, P.; Hartman, K.; Kim, S. B.; Heo, J.; Sun, L.; Hejin Park, H.; Chakraborty, R.; Buonassisi, T.; Gordon, R. G., Enhancing the efficiency of SnS solar cells via band-offset engineering with a zinc oxysulfide buffer layer. Appl. Phys. Lett. 2013, 102, 053901/1-053901/5.

(7) Lee, Y. S.; Heo, J.; Siah, S. C.; Mailoa, J. P.; Brandt, R. E.; Kim, S. B.; Gordon, R. G.; Buonassisi, T., Ultrathin amorphous zinc-tinoxide buffer layer for enhancing heterojunction interface quality in metal-oxide solar cells. Ener. \& Environ. Sci. 2013, 6, 21122118.

(8) Han, J. H.; Chung, Y. J.; Park, B. K.; Kim, S. K.; Kim, H.-S.; Kim, C. G.; Chung, T.-M., Growth of p-Type Tin(II) Monoxide Thin Films by Atomic Layer Deposition from Bis(1-dimethylamino-2-methyl2propoxy)tin and H2O. Chem. Mater. 2014, 26, 6088-6091.

(9) Baek, I.-H.; Pyeon, J. J.; Song, Y. G.; Chung, T.-M.; Kim, H.-R.; Baek, S.-H.; Kim, J.-S.; Kang, C.-Y.; Choi, J.-W.; Hwang, C. S.; Han, J. H.; Kim, S. K., Synthesis of SnS Thin Films by Atomic Layer Deposition at Low Temperatures. Chem. Mater. 2017, 29, 81008110.

(10) Browning, R.; Plachinda, P.; Padigi, P.; Solanki, R.; Rouvimov, S., Growth of multiple WS2/SnS layered semiconductor heterojunctions. Nanoscale 2016, 8, 2143-2148.

(11) Ahn, J.-H.; Lee, M.-J.; Heo, H.; Sung, J. H.; Kim, K.; Hwang, H.; Jo, M.-H., Deterministic Two-Dimensional Polymorphism Growth of Hexagonal n-Type $\mathrm{SnS}_{2}$ and Orthorhombic p-Type SnS Crystals. Nano Lett. 2015, 15, 3703-3708.

(12) Caraveo-Frescas, J. A.; Nayak, P. K.; Al-Jawhari, H. A.; Granato, D. B.; Schwingenschlögl, U.; Alshareef, H. N., Record Mobility in Transparent p-Type Tin Monoxide Films and Devices by Phase Engineering. ACS Nano 2013, 7, 5160-5167.

(13) Kelvin, H. L. Z.; Kai, X.; Mark, G. B.; Russell, G. E., P-type transparent conducting oxides. J. Phys.: Condens. Matter 2016, 28, 383002/1-383002/17.

(14) http://www.zsw-bw.de CIGS 21.7\%. Press release on September 19, 2014.

(15) http://firstsolar.com, CdTe 20.4\%. Press release on February 25th, 2014.

(16) Wang, W.; Winkler, M. T.; Gunawan, O.; Gokmen, T.; Todorov, T. K.; Zhu, Y.; Mitzi, D. B., Device Characteristics of CZTSSe Thin-Film Solar Cells with 12.6\% Efficiency. Adv. Ener. Mater. 2014, 4, 1301465/1-1301465/5.

(17) Chen, S.; Walsh, A.; Gong, X.-G.; Wei, S.-H., Classification of Lattice Defects in the Kesterite $\mathrm{Cu}_{2} \mathrm{ZnSnS}_{4}$ and $\mathrm{Cu}_{2} \mathrm{ZnSnSe}_{4}$ EarthAbundant Solar Cell Absorbers. Adv. Mater. 2013, 25, 1522-1539.
(18) Park, J. S.; Kim, S.; Xie, Z.; Walsh, A., Point defect engineering in thin-film solar cells. Nat. Rev. Mater. 2018, 3, 194210.

(19) Kim, S.; Park, J.-S.; Walsh, A., Identification of Killer Defects in Kesterite Thin-Film Solar Cells. ACS Ener. Lett. 2018, 3, 496500.

(20) Steinmann, V.; Jaramillo, R.; Hartman, K.; Chakraborty, R.; Brandt, R. E.; Poindexter, J. R.; Lee, Y. S.; Sun, L.; Polizzotti, A.; Park, H. H.; Gordon, R. G.; Buonassisi, T., 3.88\% Efficient Tin Sulfide Solar Cells using Congruent Thermal Evaporation. Adv. Mater. 2014, 26, 7488-7492.

(21) Sun, L.; Haight, R.; Sinsermsuksakul, P.; Kim, S. B.; Park, H. H.; Gordon, R. G., Band alignment of $\operatorname{SnS} / \mathrm{Zn}(\mathrm{O}, \mathrm{S})$ heterojunctions in SnS thin film solar cells. Appl. Phys. Lett. 2013, 103, 181904/1$181904 / 5$.

(22) Rath, T.; Gury, L.; Sanchez-Molina, I.; Martinez, L.; Haque, S. A., Formation of porous $\mathrm{SnS}$ nanoplate networks from solution and their application in hybrid solar cells. Chem. Commun. 2015, 51, 10198-10201.

(23) Ham, G.; Shin, S.; Park, J.; Choi, H.; Kim, J.; Lee, Y.-A.; Seo, H.; Jeon, H., Tuning the Electronic Structure of Tin Sulfides Grown by Atomic Layer Deposition. ACS Appl. Mater. \& Interfaces 2013, 5, 8889-8896.

(24) Burton, L. A.; Whittles, T. J.; Hesp, D.; Linhart, W. M.; Skelton, J. M.; Hou, B.; Webster, R. F.; O'Dowd, G.; Reece, C.; Cherns, D.; Fermin, D. J.; Veal, T. D.; Dhanak, V. R.; Walsh, A., Electronic and optical properties of single crystal SnS2: an earthabundant disulfide photocatalyst. J. Mater. Chem. A 2016, 4, 13121318.

(25) George, S. M., Atomic Layer Deposition: An Overview. Chem. Rev. 2010, 110, 111-131.

(26) Puurunen, R. L., Surface chemistry of atomic layer deposition: A case study for the trimethylaluminum/water process. J. Appl. Phys. 2005, 97, 121301/1-121301/46.

(27) Miikkulainen, V.; Leskelä, M.; Ritala, M.; Puurunen, R. L., Crystallinity of inorganic films grown by atomic layer deposition: Overview and general trends. J. Appl. Phys. 2013, 113, 021301.

(28) Zhao, L.-D.; Lo, S.-H.; Zhang, Y.; Sun, H.; Tan, G.; Uher, C.; Wolverton, C.; Dravid, V. P.; Kanatzidis, M. G., Ultralow thermal conductivity and high thermoelectric figure of merit in SnSe crystals. Nature 2014, 508, 373-377.

(29) Vidal, J.; Lany, S.; Francis, J.; Kokenyesi, R.; Tate, J., Structural and electronic modification of photovoltaic SnS by alloying. J. Appl. Phys. 2014, 115, 113507/1-113507/6.

(30) Jaramillo, R.; Steinmann, V.; Yang, C.; Hartman, K.; Chakraborty, R.; Poindexter, J. R.; Castillo, M. L.; Gordon, R.; Buonassisi, T., Making Record-efficiency SnS Solar Cells by Thermal Evaporation and Atomic Layer Deposition. JoVE 2015, (99), e52705.

(31) Kim, S. B.; Yang, C.; Powers, T.; Davis, L. M.; Lou, X.; Gordon, R. G., Synthesis of Calcium(II) Amidinate Precursors for Atomic Layer Deposition through a Redox Reaction between Calcium and Amidines. Angew. Chem. Int. Ed. 2016, 55, 1022810233.

(32) Kim, S. B.; Jayaraman, A.; Chua, D.; Davis, L. M.; Zheng, S.-L.; Zhao, X.; Lee, S.; Gordon, R. G., Obtaining a Low and Wide Atomic Layer Deposition Window $\left(150-275^{\circ} \mathrm{C}\right)$ for $\mathrm{In}_{2} \mathrm{O}_{3}$ Films Using an In ${ }^{\mathrm{III}}$ Amidinate and $\mathrm{H}_{2} \mathrm{O}$. Chem. - A Eur. J. 2018, 24, 9525-9529.

(33) Bakke, J. R.; Jung, H. J.; Tanskanen, J. T.; Sinclair, R.; Bent, S. F., Atomic Layer Deposition of CdS Films. Chem. Mater. 2010, 22, 4669-4678.

(34) Bakke, J. R.; King, J. S.; Jung, H. J.; Sinclair, R.; Bent, S. F., Atomic layer deposition of $\mathrm{ZnS}$ via in situ production of $\mathrm{H}_{2} \mathrm{~S}$. Thin Solid Films 2010, 518, 5400-5408.

(35) Sarkar, S. K.; Kim, J. Y.; Goldstein, D. N.; Neale, N. R.; Zhu, K.; Elliott, C. M.; Frank, A. J.; George, S. M., In 2 S3 Atomic Layer Deposition and Its Application as a Sensitizer on $\mathrm{TiO}_{2}$ Nanotube 
Arrays for Solar Energy Conversion. J. Phys. Chem. C 2010, 114, 8032-8039.

(36) Nykanen, E.; Laine-Ylijoki, J.; Soininen, P.; Niinisto, L.; Leskela, M.; Hubert-Pfalzgraf, L. G., Growth of PbS thin films from novel precursors by atomic layer epitaxy. J. Mater. Chem. 1994, 4, 1409-1412.

(37) Meng, X.; Libera, J. A.; Fister, T. T.; Zhou, H.; Hedlund, J. K.; Fenter, P.; Elam, J. W., Atomic Layer Deposition of Gallium Sulfide Films Using Hexakis(dimethylamido)digallium and Hydrogen Sulfide. Chem. Mater. 2014, 26, 1029-1039.

(38) Dasgupta, N. P.; Meng, X.; Elam, J. W.; Martinson, A. B. F., Atomic Layer Deposition of Metal Sulfide Materials. Acc. Chem. Res. 2015, 48, 341-348.

(39) Harrison, P. G.; Zuckerman, J. J., $\left(\mathrm{C}_{5} \mathrm{H} 5\right)_{2} \mathrm{Sn}: \rightarrow \mathrm{BF}_{3}$. The first example of a tin .far. Group III complex. J. Am. Chem. Soc. 1970, 92, 2577-2578.

(40) Dave, L. D.; Evans, D. F.; Wilkinson, G., 749. The structures of dicyclopentadienyl-tin and -lead.J. Am. Chem. Soc 1959, 0, 3684-3688.

(41) Bos, K. D.; Bulten, E. J.; Noltes, J. G., Oxidative addition reactions of some organotin(II) and organic tin(II) compounds [1]. J. Organomet. Chem. 1974, 67, C13-C15.

(42) Puurunen, R. L., Growth Per Cycle in Atomic Layer Deposition: A Theoretical Model. Chem. Vap. Deposition 2003, 9, 249-257.

(43) Zhao, R.; Guo, Z.; Wang, X., Surface Chemistry during Atomic-Layer Deposition of Nickel Sulfide from Nickel Amidinate and $\mathrm{H}_{2} \mathrm{~S}$. J. Phys. Chem. C 2018, 122, 21514-21520.

(44) Nair, P. K.; Garcia-Angelmo, A. R.; Nair, M. T. S., Cubic and orthorhombic SnS thin-film absorbers for tin sulfide solar cells. Phys. Status solidi A 2016, 213, 170-177.

(45) Zhang, Y.; Reeder, E. K.; Keaton, R. J.; Sita, L. R., Goldilocks Effect of a Distal Substituent on Living Ziegler-Natta Polymerization Activity and Stereoselectivity within a Class of Zirconium Amidinate-Based Initiators. Organometallics 2004, 23, 3512-3520. 
SYNOPSIS TOC

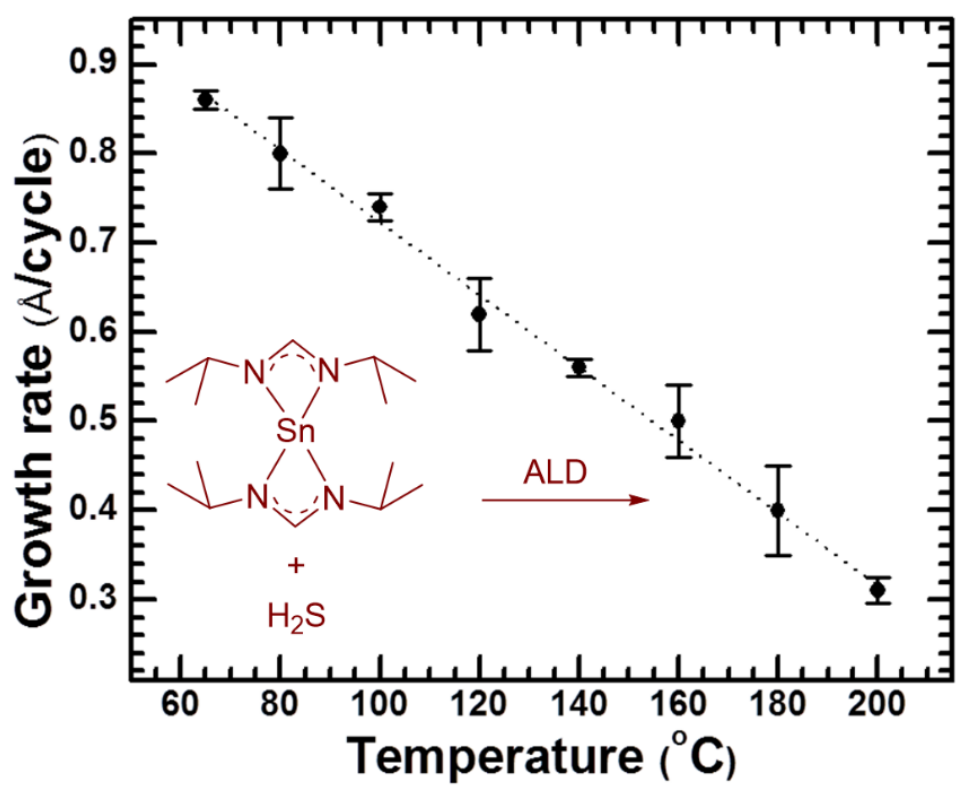

